\title{
TEORIA SYSTEMÓW-ŚWIATÓW \\ IMMANUELA WALLERSTEINA I JEJ RECEPCJA \\ W ARCHEOLOGII: \\ CZĘŚĆ III - OKRES WPLYWÓW RZYMSKICH
}

\section{IMMANUEL WALLERSTEIN'S CENTRE-PERIPHERY THEORY AND ITS RECEPTION IN ARCHAOLOGY, PART III IRON AGE}

\author{
Adriana Ciesielska \\ Zakład Zasobów Poznawczych Człowieka \\ Wydział Pedagogiczno-Artystyczny \\ Uniwersytet im. Adama Mickiewicza, Poznań - Kalisz, Poland \\ adrianac@wp.pl
}

\begin{abstract}
Immanuel Wallerstein's centre-periphery model lies at the root of many archaeological studies, particularly studies of romanisation. One of them has been an article written by Peter S. Wells, but we have also studies done by Richard Higley concerning Roman Britain, Susan Frankenstein and Michael Rowland concerning the social hierarchy in Roman Germany. Actually several archaeologists tried to study these topic according to the Wallerstein's world-systems theory. We can observe that the application of the theory into archaeology has always very important heuristic value.
\end{abstract}

KEY WORDS: goods, production, exchange, power, social system

Model systemów-światów Immanuela Wallersteina, zwany także modelem centrum-peryferii, leży u podłoża wielu poszukiwań w obrębie studiów nad romanizacją. Odgrywa on decydującą rolę przy opisywaniu interakcji między Półwyspem Apenińskim, kulturami Morza Śródziemnego i ich peryferiami. W okresie wpływów rzymskich, zgodnie z chronologią europejską, możemy doszukiwać się takich właśnie zależności. 


\section{SPUŚCIZNA IMMANUELA WALLERSTEINA}

Immanuel Wallerstein dał początek szerokim studiom i dyskusjom na temat powstawania i funkcjonowania wielkich geograficznych obszarów tworzących jeden polityczno-ekonomiczno-kulturowy system. Wymiana w tak wielkim systemie-świecie postrzegana jest nie jako równa i sprawiedliwa, lecz jako nierówno podzielona między centrum i peryferie. Peryferie są rozumiane jako obszary eksploatowane, dostarczyciele głównie surowców naturalnych.

Dla zrozumienia tej charakterystycznej dla systemu-świata nierównej wymiany fundamentalny jest przestrzenny podział różnorodnych stosunków i relacji produkcji. Podczas gdy w centrum dominuje praca płatna przy wytwarzaniu wysoko przetworzonych towarów, w peryferiach dominuje praca niewolnicza albo przymusowa przy pozyskiwaniu surowców naturalnych czy też przy wytwarzaniu produktów żywnościowych. W strefie pośredniczącej między centrum i peryferią, w tym modelu nazywanej półperyferią, dominuje model feudalny.

Powyżej zarysowałam tradycyjne definicje systemu-świata charakterystyczne dla nowożytnej, kapitalistycznej Europy. Nie powinno być zaskoczenia, że główna praca I. Wallersteina $(1975,1980)$ udowodniła, że jest źródłem inspiracji dla wielu archeologów, szczególnie dla osób zajmujących się Rzymem i jego oddziaływaniem, w szczególności interesujących się wzorami i zjawiskami na ogromnie rozległych przestrzeniach. Analizy Wallersteina są często, wbrew intencji autora, stosowane do okresów przed pojawieniem się kapitalizmu w Europie, co sam autor datuje dopiero na XV wiek n.e. Wallerstein nigdy nie interesował się osobiście wcześniejszymi niż kapitalizm systemami, co nie oznacza, że w jego pracach nie ma miejsca na choćby zarys próby ich zdefiniowania. Czynił to w dwóch pierwszych tomach swojego wielkiego dzieła, usiłując ulokować kapitalizm w historii świata i zbadać jego korzenie. Świat starożytny został przy tym wykorzystany przez Wallersteina do ukazania kontrastu między nim a światem nowożytnym. Starożytne imperia-światy, mini-systemy i gospodarki-światy miały mu pomóc wykazać szczególną naturę i cechy charakterystyczne tylko dla kapitalizmu.

Najogólniej poglądy Wallersteina można streścić następująco: Aż do całkiem niedawnych czasów w historii świata większość ludzkiej aktywności, zwłaszcza społecznej, przebiegała w mini-systemach, które były luźnym zgrupowaniem małej liczby ludzi. Mini-systemy były niestabilne i żyły względnie krótko. W ostatnich dwóch tysiącleciach historia świata zdominowana jest przez wzrosty i upadki systemów-światów, których były dwa rodzaje: zjednoczone politycznie imperia-światy i gospodarki-światy charakteryzujące się tylko powiązaniami gospodarczymi. Przy czym zdaniem Wallersteina w starożytności większość gospodarek-światów była przekształcana gwałtownie w imperia-światy przez ekspansję jednej z rządzących grup w jakimś historycznym regionie. Poniżej postaram się pozbierać rozproszone wzmianki Wallersteina na temat imperiów-światów i gospodarek-światów charakteryzujących okres starożytny. 


\section{DEFINICJA IMPERIUM-ŚWIATA}

Dla osób zajmujących się Imperium Rzymskim analiza systemów-światów ma dużą atrakcyjność, zwłaszcza przy śledzeniu zjawisk gospodarczych, a nawet społecznych. Po pierwsze analiza ta zajmuje się wzorami zachowań na wielką skalę, zarówno geograficzną, jak i chronologiczną. Po drugie analiza ta odrzuca kategorie pojęciowo zamknięte, takie jak indywidualne społeczeństwa czy państwa narodowe. Po trzecie analiza ta oferuje podejście gotowe do tworzenia uogólnień na ponadregionalną skalę dużych struktur charakteryzujących się pewną dynamiką rozwoju. To wszystko jest bardzo atrakcyjne dla studiów nad romanizacją.

Pierwszy typ struktury, którą Wallerstein odnosi do świata starożytnego, to imperium-świat. Imperium-świat jest typem systemu-świata, który zdaniem autora modelu poprzedzał kapitalistyczną gospodarkę-świat zbudowaną dopiero w XVI wieku. Imperia-światy jego zdaniem mogą powstać na drodze ewolucji z gospodarek-światów, w sytuacji gdy dominujące staje się polityczne panowanie jednego państwa nad dużym obszarem gospodarczym. Chociaż Wallerstein nie rozwija w swoich pracach tego pojęcia, jego zdaniem imperium-świat charakteryzuje się trzema kluczowymi cechami: 1) przeciwstawionymi sobie regionami, z których jeden stanowi centrum, a pozostałe peryferie; 2) koncentryczną organizacją produkcji; 3) modułową strukturą, która jest efektem powstania systemu z kilku wcześniejszych, niezależnych od siebie mini-systemów. Oryginalność tego pojęcia leży w ujęciu imperium jako systemu-świata. Imperium-świat może być więc rozważane w kategoriach zarówno struktury, jak i jego dynamiki. Strukturalną, najbardziej oczywistą cechą jest opozycja między centrum i peryferią. Wallerstein ujął to następująco:

Imperia-światy były trwałą cechą sceny świata przez pięć tysięcy lat. W różnych częściach świata istniało trwale kilka takich imperiów w danym punkcie w czasie. Polityczna centralizacja imperium była zarazem i jego siłą, i jego słabością. Jako siła leżała ona w fakcie, że gwarantowała ekonomiczny przepływ z peryferii do centrum trybutu i opodatkowania, a także możliwość monopolizacji korzyści przynoszących przez handel. (1975, s. 15)

W imperium-świecie Wallerstein najprawdopodobniej nie zakładał istnienia półperyferii, chociaż nie dyskutuje na ten temat. W tym modelu najprawdopodobniej rolę tę pełnią handlarze i element miejski politycznie pozbawiony praw, którym centralna władza pozwala na zachowanie pewnej sumy produkowanych nadwyżek. Tak więc widzimy, że w imperium-świecie podział pracy zachodzi w obrębie społeczeństwa, zaś w kapitalizmie jest to już międzynarodowy podział pracy.

Dalej Wallerstein pisze (1979, s. 390), że: „Imperium-świat ekspanduje do społeczno-technicznych granic efektywnej kontroli politycznej procesu redystrybucji”. Greg Woolf (1990, s. 46) na podstawie tej wzmianki wnosi, że imperium-świat po- 
winno być zasadniczo koncentrycznie zorganizowane wokół swojego centrum, zaś promień tego okręgu powinien być warunkowany przez równowagę zachodzącą między kosztami utrzymania imperium i jego dochodami. Wallerstein oparł się w tych szacunkach na pracy Braudela (1972), sugerując, że typowy promień odpowiadał około trzydziestodniowej podróży dla obu kategorii systemów-światów. Jego zdaniem ekspansję ogranicza obecność w pobliżu innych imperiów-światów. Przyległe imperia mogą bowiem konkurować o kontrolę nad obszarami będącymi peryferyjnymi dla nich obu.

W obrębie swoich granic imperium-świat nie jest homogeniczną całością: „W obrębie przestrzennego podziału pracy rozkwitło wiele różnych kultur, były to równoległe grupy producentów rolniczych, grupy handlujące z całym światem, rodzime grupy zajmujące się administrowaniem, które zmieniały swe położenie. Kluczowym pojęciem tego sposobu produkcji jest polityczna jedność gospodarki” (Wallerstein, 1976, s. 347).

Greg Woolf (1990, s. 47) rozwija tę myśl, pisząc, że tworzenie się imperium może obejmować unifikację kulturową warstw rządzących, które wywodzą się z poprzednio niepodległych państw, podczas gdy poddane im populacje pozostają tak samo rozdrobnione jak przed podbojem. Wynika $\mathrm{z}$ tych rozważań, że imperium-świat może być złożone komórkowo, jest sformowane z pewnej ilości poprzednio niezależnych mini-systemów, które teraz płacą trybut centrum. W obrębie takiej komórki jest element lokalnej warstwy rządzącej i zależnych od niej handlarzy i administracji. Obraz ten można porównać do koncepcji peer polity interaction Colina Renfrew, która jednak nie była znana Wallersteinowi.

Struktura imperium-świata jest przez Wallersteina lepiej opisana niż jej dynamika. Wiemy tylko, że imperia-światy są olbrzymimi strukturami, które cyklicznie ekspandują, aby po największym szczycie ekspansji powrócić do swoich pierwotnych wąskich granic. Czasami nie ma powrotu i imperia-światy rozpadają się. Konkretne obszary geograficzne można scharakteryzować przez pewną kolejność następowania po sobie imperium-światów, które raz ekspandują, a raz wracają do swoich początkowych granic. Jednak ta ekspansja i powrót kierowane są zdaniem Wallersteina przez zupełnie inne siły niż ekspansja kapitalizmu:

nowożytny system-świat jest całością ekonomiczną, a nie polityczną, w odróżnieniu od imperiów-światów, miast-państw i państw-narodów. Podstawowe powiązanie pomiędzy nim a jego częściami jest ekonomiczne.

Imperia-światy są z zasady redystrybucyjne w swej ekonomicznej formie. Pojawiają się w nich skupiska kupców, którzy angażują się zasadniczo w handel dalekosiężny, a więc w wymianę ekonomiczną, lecz takie skupiska były mniejszą częścią całkowitej ekonomii i zasadniczo nie decydowały o losie imperium. (Wallerstein, 1975, s. 15)

Tak więc ogląd starożytnych gospodarek według Wallersteina jest bardzo bliski substantywizmowi Karla Polanyi i ideom Mosesa Finleya. 
Elementem różniącym imperium-świat od gospodarki-świata jest idea relacji między władzami ekonomiczną i polityczną. Przed XV wiekiem dominowali władcy, którym kupcy byli podporządkowani jako poddani, władcy mieli nad nimi kontrolę, zaś kupcy byli zmuszeni do służenia ich potrzebom. Imperia-światy zatem ekspandowały i kurczyły się w zgodzie z bodźcami politycznymi albo militarnymi, a nie ekonomicznymi.

Inne cechy starożytnego świata mogą być tożsame z cechami nowożytnego systemu-świata, dotyczy to na przykład cykli wzrostu i recesji, które są wynikiem zmieniającego się napięcia między strefą centrum a terenami od niego zależnymi. Również zjawisko osłabiania terenów zależnych przez jego kontakty z centrum może być postrzegane jako typowy „rozwój niedorozwoju” w kategoriach Andre Gunder Franka.

\section{PRZEDKAPITALISTYCZNE GOSPODARKI-ŚWIATY}

Imperia-światy zajmowały dużą część świata starożytnego, ale nie cały. Jak ujął to Wallerstein (1987, s. 317): „Kiedykolwiek jedno imperium-świat ekspanduje i jest zniszczone czy też wchłonięte do zarówno mini-systemów, jak i gospodarek-światów, i kiedykolwiek jedno imperium-świat cofa się do swoich poprzednich granic, otwiera ono przestrzeń dla odtworzenia się mini-systemów i gospodarek-światów".

Z rozważań Wallersteina wynika też jednoznacznie, że w starożytności możliwe były także gospodarki-światy, które nie były kapitalistyczne.

Studia archeologiczne starożytności w chwili obecnej już za pewnik biorą prawdopodobieństwo istnienia szerokich sieci wymiany, które tworzyły wzory ponadregionalne przekształcające strukturę społeczną i kulturę materialną na całym naszym kontynencie. Wallerstein przyjął jednak, że handel dalekosiężny nie był ważny w społecznej ewolucji, zanim nie pojawił się kapitalizm. Jego zdaniem wymiana między gospodarkami-światami to była wymiana dóbr luksusowych, handel był równy, jakby stojąc w opozycji do nierównego handlu charakterystycznego dla kapitalizmu.

W starożytności gospodarki-światy były niestabilnymi całościami, które albo bardzo szybko upadały, albo zostały przekształcone w imperia-światy. Gospodarki-światy Wallerstein (1987, s. 37) nazywa „olbrzymimi nierównymi łańcuchami zintegrowanych struktur produkcji przeciętnymi wielokrotnymi strukturami politycznymi. Logika, że akumulowana nadwyżka jest dystrybuowana nierówno na korzyść tych będących w stanie osiągnąć różny rodzaj czasowego monopolu w rynkowych sieciach, jest jednak logiką kapitalizmu".

Zdaniem Grega Woolfa (1990, s. 51) starożytne i nowożytne gospodarki-światy można postrzegać jako podobne. Jedyną cechą różniącą je od siebie było to, że starożytne imperia-światy swoimi działaniami politycznymi szybko kruszyły i niszczyły budujące się dopiero gospodarki-światy. Zdaniem Wallersteina nowożytny 
system-świat osiągnął stabilność dzięki zmianom technologicznym. Jego twierdzenie, że wcześniejsze gospodarki-światy były niestabilne i przez to nieważne, jest elementem jego wyjaśniania różnic między starożytnością a nowożytnością.

Jeżeli chodzi o kontynuację prac archeologicznych nad zarysowanym przez Wallersteina modelem, to można wyróżnić w tym miejscu dwie grupy archeologów. Pierwsza z tych grup uważa, że dobra luksusowe miały znaczenie ekonomiczne, zaś druga grupa przywołuje tylko ich społeczne znaczenie. Zdaniem Grega Woolfa (1990, s. 51) dobra luksusowe są bardzo ważne ekonomicznie ze względu na ich wysoką wartość w przeliczeniu na jednostkę miary lub wielkości. Ta właśnie wartość sprawia, że handel dalekosiężny w warunkach starożytnego transportu był opłacalny, zyskowny i stanowił podstawą indywidualnych fortun. Powodował też, że wyprawy dalekosiężne stały się ryzykownymi przedsięwzięciami ekonomicznymi, których zysk pojawiał się dopiero po długim czasie, kiedy handlarz wracał z towarem do miejsca wyjścia. Wiemy także, że handel dobrami luksusowymi miał znaczenie społeczne proporcjonalne do ekonomicznej wartości tego rodzaju dóbr. Tak więc z obserwacji archeologicznych wynika, że tego typu dobra wcale nie były nieistotne. Wiemy, że służyły do odtwarzania hierarchii społecznej. Z tego typu badań zdaniem Grega Woolfa (1990, s. 51-52) wyrasta kluczowe pytanie: Na ile handel dobrami luksusowymi sprawiał, że lokalne elity naprawdę były zależne od centrum? Dobra luksusowe osiągające społeczne znaczenie stawały się więc dobrami prestiżowymi. Nie musiały być one importami, mogły być wytwarzane lokalnie i jako dobra prestiżowe służyły tak długo, jak długo główni wodzowie zachowali kontrolę nad produkującymi je rzemieślnikami, ich technikami i nad koniecznymi surowcami.

\section{CZY RZYM BYL IMPERIUM-ŚWIATEM, CZY GOSPODARKĄ-ŚWIATEM}

Pytanie postawione w tej części artykułu wynika z mojej powyższej analizy. Zarysowałam w niej definicje dwóch kategorii zaproponowanych przez I. Wallersteina i postarałam się znaleźć mówiące o nich cytaty z jego najważniejszych prac. Teraz chcę skoncentrować swoją uwagę na szczytowej formie Imperium Rzymskiego w II wieku n.e. W tym okresie Imperium Rzymskie było kontrolowane z centralnie położonej stolicy - Rzymu. To do niej kierowany był napływ trybutu i opodatkowania. Elementem niezwykłym i od razu rzucającym się w oczy jest również napływ środków finansowych do położonych na granicach imperium armii. Armie ulokowane wzdłuż granic są głównym konsumentem dóbr w Imperium Rzymskim w tym okresie. Imperium nie jest więc koncentryczne, jakby tego chciała koncepcja Wallersteina imperium-świata.

Opisywana sytuacja zmienia się w Imperium Rzymskim w III wieku n.e., wtedy na obszarze Bliskiego Wschodu ustanowione zostaje nowe imperium-świat, a mia- 
nowicie Persja. Jako rezultat w Cesarstwie Rzymskim zmienia się położenie stolicy - przenosi się ona do Konstantynopola. Nie do końca wiadomo, jakie motywy leżały u podstaw takiej decyzji, być może redukcja czasu przekazywania informacji z Bliskiego Wschodu do stolicy. W tym wieku również zaczęto prowadzić eksperymenty związane z decentralizacją Imperium Rzymskiego. Dały one w rezultacie fragmentację imperium, a w końcu zaowocowały utratą zachodnich imperialnych terytoriów położonych najdalej od nowego centrum.

Natomiast mogę przyznać, że Imperium Rzymskie było komórkowe. Niektóre jego komórki miały swój początek we wcześniejszych imperiach-światach, takich jak Egipt i Azja. Niektóre, jak Sycylia, były przegrupowaniem komórek z wcześniejszych imperiów. Zaś jeszcze inne, takie jak Zachód, były wcześniejszymi niepodległymi jednostkami politycznymi (mini-systemami).

Na pewno w obrębie Imperium Rzymskiego nie można zidentyfikować obszaru, który można by ująć jako półperyferię. Wydaje się, że wewnętrzne prowincje były bardziej eksploatowane niż prowincje zewnętrzne. Inne analizy, jak na przykład Whittakera (1994), sugerują, że półperyferyjne strefy istniały poza granicami imperium, które w jakimś sensie pośredniczyły między prowincjami a niepodległymi barbarzyńskimi strefami. Na pewno istniała taka strefa wzdłuż północnej granicy imperium, która była kontrolowana zarówno przez rzymską dyplomację, jak i do pewnego stopnia penetrowana przez handlarzy rzymskich. Pytaniem otwartym pozostaje, czy była ona strefą półperyferyjną między centrum i peryferią ówczesnego świata, czy też była tylko strefą między imperium-światem a zewnętrznymi grupami.

Dynamika Imperium Rzymskiego jest dużo łatwiejsza do analizowania w kategoriach systemów-światów niż imperium-świata, być może wynika to z tego, że koncepcji imperium-świata brakuje precyzji. Wśród historyków panuje zgoda co do tego, że handel w imperium był podporządkowany celom i potrzebom politycznym. Handel był warunkowany strukturami społecznymi i wartościami społecznymi. Polityczne i militarne środki nie służyły celom komercyjnym.

Kwestią dyskusyjną jest także postrzeganie sposobów produkcji w ramach olbrzymiego imperium. W tym problemie mieści się pytanie o dominację i wzrost niewolniczego sposobu produkcji w Italii $\mathrm{w}$ dobie republiki i wczesnego cesarstwa. Możni rzymscy byli oczywiście świadomi korzyści, jakie niosła ze sobą ekspansja, lecz raczej postrzegali ją w kategoriach grabieży i sławy. Ekspansja ustała w czasach Augusta, gdy została zbudowana infrastruktura potrzebna do systematycznego pozyskiwania trybutu. Wówczas także na terenie imperium opodatkowano rolnictwo.

Dyskusyjne są również powody, które przyczyniły się do końca rzymskiej ekspansji. Mamy kilka różnych opinii na ten temat, z jednej strony mówi się o ograniczeniach ekologicznych, środowiskowych. Z drugiej strony sugerujemy, że podbój rzymski był ograniczony do tych społeczeństw, które miały wystarczająco rozwiniętą infrastrukturę, aby same mogły zbierać i płacić trybut. Czy też być może była to 
zmiana postawy arystokracji w obrębie imperium. Ważne jest to, że koniec ekspansji rzymskiej nie wywołał wewnętrznego kryzysu i był oddzielony przez kilka wieków od kurczenia się strefy imperium w $\mathrm{V}$ wieku n.e.

W odpowiedzi na pytanie tytułowe nie pomaga także rozważenie kwestii, czy standard życia mieszkańców prowincji polepszył się, czy pogorszył od czasu podboju rzymskiego. Wiemy, że wzrosło w tym czasie opodatkowanie, ale pewnym regionom nadawane były także przywileje, nie jest więc jasne, jak można te zmiany wpisać w model rozwoju niedorozwoju. Natomiast wiemy, że niezwykle trudne jest śledzenie cyklicznych trendów w obrębie tak rozległego imperium.

Podsumowując, widać, że Imperium Rzymskie koresponduje dobrze z koncepcją imperium-świata Wallersteina, a tam, gdzie jest ona nieprecyzyjna, można niektóre zjawiska usiłować wyjaśniać za pomocą kategorii charakterystycznych dla gospodarek-światów. Jestem pewna, że proponowana analiza systemu-świata może dostarczyć schematu badań stawiających pytania do tej pory nieanalizowane w studiach nad Imperium Rzymskim.

\section{APLIKACJA MODELU WALLERSTEINA DO STUDIÓW NAD ROMANIZACJĄ}

Dotychczasowe usiłowania aplikacji modelu I. Wallersteina do studiów nad romanizacją zostały skrytykowane najpierw przez Christopha Kümmela (2001), a następnie przez Günthera Schörnera (2005).

W swej pracy Ch. Kümmel (2001) zaproponował typologię form, w jakich następuje zazwyczaj aplikacja i recepcja modelu Wallersteina $\mathrm{w}$ studiach nad romanizacją: 1) bezpośrednie odwołanie się tylko do prac I. Wallersteina; 2) podejście dóbr prestiżowych, w których ruch produktów luksusowych śledzony jest między obszarami uznanymi za centralne i peryferyjne; 3) podejście makrohistoryczne, pokazujące większe, ponadregionalne związki; 4) użycie tylko pojęć centrum i peryferii bez akceptacji teoretycznej refleksji związanej z tymi dwoma pojęciami.

W artykule tym interesuje mnie tylko pierwszy typ wyróżnionych prac. Zaliczam do niego artykuły Richarda Hingleya z 1982 r. Roman Britain: the structure of Roman imperializm and the consequences of imperialism in the development of a peripheral province oraz artykuł i książki Petera Wellsa z 1980 r. Culture Contact and Culture Change: Early Iron Age Central Europe and the Mediterranean World, z 1993 r. Settlement, Economy and Cultural Change at the End of the European Iron Age: Excavations at Kelheim in Bavaria 1987-1991, a także artyku1 z 1996 r. Production within and Beyond Imperial Boundaries, Goods, Exchange and Power In Roman Europe. 
Ważny także, choć niewychodzący bezpośrednio z koncepcji Wallersteina, lecz z koncepcji Edwarda Shielsa centrum-peryferii, jest artykuł Grega Woolfa z 1990 r. zatytułowany World-systems analysis and the Roman empire. Omówię kolejno te prace i zawarte w nich koncepcje.

W tym miejscu nie zajmuję się badaniami typu drugiego, nazwanego podejściem dóbr prestiżowych, którego najlepszym przykładem jest artykuł Susan Frankenstein i Michaela Rowlandsa z $1978 \mathrm{r}$. The internal structure and regional context of early iron age society in south-west Germany.

\section{GOSPODARCZY ROZWÓJ BRYTANII}

Jak już zwróciłam uwagę, R. Hingley w artykule z 1982 r. usiłuje nawiązać bezpośrednio do teorii systemów-świata I. Wallersteina w odpowiedzi na pytanie o zależność gospodarczego rozwoju rzymskiej Brytanii od Rzymu. Hingley traktuje tę prowincję jako wykorzystywany gospodarczo podbity teren, zaś Rzym jako potęgę kolonizującą. Jego zdaniem Rzymianie napłynęli do Brytanii, aby ustanowić w niej zwarty system panowania, aby móc wyprodukowane w Brytanii nadwyżki wysyłać do Rzymu. Hingley wyróżnił pod tym względem trzy różne pola działań: 1) obszar między prowincjami, 2) powierzchnię prowincji, 3) powierzchnię plemienną obejmującą miasta i ich zaplecze wiejskie.

Dla Hingleya relacja centrum-peryferii jest przede wszystkim relacją ekonomiczną. Hingley uważa, że z Brytanii do Rzymu systematycznie przypływały surowce naturalne, niewolnicy i dobra rolne. Rzym w drugą stronę dostarczał wysoko wartościowych gotowych produktów, które w Brytanii funkcjonowały jako symbole statusu i były właściwym medium romanizacji. W prowincji Brytania Rzymianie stworzyli centrum administracyjne w Londinum (Londynie), które było porównywalne do centrum w Rzymie. Hingley dopatruje się dwóch poziomów relacji centrum-peryferii. Pierwszy z nich to poziom między prowincjami, gdzie Rzym stanowi centrum, a Brytania jest prowincją. Drugim z nich jest poziom plemienny, gdzie miasto stanowi centrum, zaś zaplecze wiejskie funkcjonuje na zasadzie prowincji. Ten drugi system kierowany jest przez lokalne elity usytuowane w centrum będącym równocześnie punktem węzłowym handlu. Elity te monopolizują zarówno handel dalekosiężny, jak i handel lokalny, a zaplecze wiejskie administracyjnie, gospodarczo, ale i społecznie zależne jest od miasta.

Według R. Hingleya wymiana między Rzymem a Brytanią, tak jak wymiana już w obrębie Brytanii między miastem a obszarami wiejskimi, jest równoległa. Obie wymiany są też zgodnie $\mathrm{z}$ definicją Wallersteina opartej na wymianie nierównej, która uprzywilejowuje zarówno Rzym, jak i miasta.

G. Schörner zarzuca tej analizie zbyt duże uproszczenia, zwłaszcza kiedy R. Hingley definiuje pojęcie centrum. 


\section{RZYMSKA EUROPA JAKO SYSTEM-ŚWIAT}

W omówieniu prac na temat romanizacji wykorzystujących model centrum-peryferii I. Wallersteina, autorstwa Ch. Kümmela oraz G. Schörnera, zabrakło analizy Petera Wellsa, który wielokrotnie $(1980,1993,1996)$ odwoływał się do modelu systemu-świata w studiach nad gospodarką okresu Republiki i Cesarstwa Rzymskiego. Dla niego najbardziej istotnym elementem tworzenia zależności prowincji od centrum jest ustanowienie systemu dostaw dla armii rzymskiej.

\section{APROWIZACJA ARMII RZYMSKIEJ JAKO ELEMENT KRYTYCZNY SYSTEMU}

Po tym jak Rzym podbił dużą część umiarkowanej Europy, administracja kierowała ustanowieniem przemysłu ważnego dla utrzymania armii i dla ekonomicznej kontroli nad nowymi prowincjami. Obejmowało to kamieniołomy, wytwórczość ceramiki i przemysł metalowy. Badania pokazują jednak, że wiele części tej produkcji nie było tak bardzo scentralizowanych, jak uważano wcześniej. Różnorodne stanowiska przemysłowe w obrębie krajobrazu prowincji wskazują dużą różnorodność organizacji dostarczania rzeczy potrzebnych imperium. W wielu przypadkach systemy produkcji rzymskiej polegały na lokalnych tradycjach wytwórczości. Gospodarka prowincjonalna zależała od materiałów zebranych i przetwarzanych poza granicami imperium. Analizy rzymskich importów w Niemczech, Skandynawii i wschodniej Europie oraz kontekstu, w jakim one występują, sugerują, że dobra produkowane poza imperium odgrywały wielką rolę $\mathrm{w}$ gospodarce imperialnej. Te handlowe związki, nad którymi rzymskie władze nie miały żadnej efektywnej kontroli, miały wkład $\mathrm{w}$ istotne zmiany $\mathrm{w}$ gospodarce oraz społecznej i politycznej organizacji w społecznościach poza granicą rzymską.

Większość tego, co wiemy i myślimy, że wiemy na temat imperiów w historii świata, dotyczy działań, motywacji i instytucji społeczności imperialnych. Względnie mało wiemy na temat ludzi, którzy są włączeni w konteksty imperialne przez podbój czy za pomocą innych środków. Większość imperiów była rozwijana przez społeczeństwa, które miały własne pismo i tworzyły pisemne sprawozdania, na których opiera się nasze rozumienie przeszłych czasów, Rzymian w większym świecie śródziemnomorskim, Hiszpanów w południowej Ameryce czy Brytyjczyków w Indiach. Opieramy się na pisarzach, którzy zasadniczo należeli do społeczeństwa imperialnego i przez to reprezentowali perspektywę członków elity tego społeczeństwa. W przypadku wczesnych imperiów, na temat których nie mamy tylu źródeł pisanych, archeologia odgrywa wielką rolę w zrozumieniu znaczenia materialnych pozostałości kultury imperialnej. Sądzimy na tej podstawie, że elementy imperialne 
są dla takich społeczeństw bardziej istotne niż dla społeczeństw, które żyły w obrębie kultury imperialnej.

Całkiem niedawno archeolodzy, historycy i antropolodzy społeczni i kulturowi zaczęli prowadzić systematyczne badania, których celem jest zrozumienie doświadczeń innych ludów zaangażowanych w interakcje z imperiami - grup podbitych przez ekspandujące imperia i te, które w jakiś inny sposób dostały się w bezpośredni kontakt z imperium. Można zająć się już dawno ustanowionym pytaniem badawczym: Jaki wpływ miały podbijające społeczeństwa na rodzime ludy? A także odpowiedzią na pytanie, którego nigdy nie zadawano: W jaki sposób ludy rodzime dowodziły swojej własnej tożsamości i utrzymywały czy też wzmacniały swoje własne systemy kulturowe w odpowiedzi na wyzwania i możliwości oferowane przez ekspandujące imperium? Mamy kilka cennych studiów, które skoncentrowały się na odpowiedzi na to ostatnie pytanie. Obejmują one na przykład prace Smitha z 1986 r., który badał elity w społeczeństwach peryferyjnych imperium Azteków, czy też D’Altroy’a z 1992 r., który zajmował się lokalnymi populacjami w imperium Inków oraz Alcocka (1993) i jego badania okupowanej przez Rzymian Grecji w 1993 r. Te studia pokazują, że ludy rodzime miały ważne wpływy na kultury imperialne. W przypadku podejmowanym w tym artykule lokalne rodzime grupy odgrywały wielką rolę $\mathrm{w}$ kierowaniu biegiem imperialnego podboju i w ustanowieniu, a potem $\mathrm{z}$ kolei $\mathrm{w}$ zarządzaniu prowincjonalnymi systemami administracji i dostaw. Pytanie, które teraz równie dobrze można postawić, to: Do jakiego stopnia władze centralne w imperium decydowały o biegu wydarzeń i do jakiego stopnia imperia są zależne od kompromisu i negocjacji ze społecznościami, które inkorporują?

Podejście systemu-świata do pytania o rolę podbitych i sąsiednich ludów w imperiach pomoże zwrócić uwagę na interakcyjny aspekt wszystkich relacji w sytuacjach imperialnych. Podbite ludy i ludy usytuowane poza imperialnymi granicami, z którymi imperium ma kontakty przez handel, wszystkie muszą być postrzegane jako część tego samego systemu-świata. My musimy postrzegać rodzime ludy nie tylko w kategoriach, jak one reagują na potęgę imperium, lecz raczej jako aktywnych uczestników w konstrukcji kontekstu interakcji. Z tej perspektywy możemy zamienić nasze centralne pytanie: Jaki wpływ miało imperium na grupę ludów rodzimych, na pytanie: Jaki wpływ na imperium miała grupa rodzima?

Archeologia może mieć wkład w ten rozwój teorii na dwa ważne sposoby. Po pierwsze archeologia może badać przypadki wczesnych imperiów i zmiany związane $\mathrm{z}$ nimi w długich okresach. W krajobrazie, w którym istnieje dobra baza danych archeologicznych, możemy badać zmieniające się okoliczności i wzory adaptacji od czasów przed podbojem przez okres podboju aż po czasy w rożnym okresie po zakończeniu istnienia imperium. Takie procesy zmiany mogą mieć miejsce w wielu wiekach i dostępność porównawczego materiału archeologicznego z rożnych okresów umożliwia studia na szeroką skalę. Po drugie w opozycji do historyków zależnych od tekstów pisanych archeolodzy mogą badać każdy poziom społeczeństwa, 
a nie tylko elity i większe społeczności, aby zebrać informacje na temat zmiany. W studiach nad materialnymi manifestacjami życia codziennego wśród większości ludów w społeczeństwie i zmianach w tych wzorach wraz z upływem czasu archeolodzy mogą zaznaczyć swój znaczny wkład w badania nad szerokim wpływem imperiów. Podczas gdy historycy pracujący z tekstami są zależni od tematów, które interesowały wczesnych pisarzy, archeolodzy mogą konsultować teoretycznie nieograniczony zakres materialnych śladów typowy dla osadnictwa, wytwórczości, handlu, wyrażania statusu i codziennego życia.

W modelu systemu-świata istotna dynamika zachodzi między systemami imperialnymi, które ekspandują $\mathrm{w}$ przestrzeni i $\mathrm{w}$ ich zdolności do pochłaniania surowców i rodzimych społeczności, które wchodzą w interakcje z imperialnymi potęgami. Szeroki zakres różnych wzorów interakcji można zidentyfikować w rożnych okolicznościach. Jak przytaczam w tym artykule, na podstawie niektórych przykładów zaczerpniętych z wczesnych imperiów możemy wnosić, że społeczeństwa imperialne mają dużo mniejszą kontrolę nad interakcjami z innymi grupami społecznymi. Fakt ten nie wynika bezpośrednio z analiz, które oparte są na modelu systemu-świata. Przypadkiem, który mnie interesuje w tym artykule, jest Imperium Rzymskie i jego wpływ na strefę centralnej Europy.

\section{IMPERIUM RZYMSKIE I JEGO WPLYW NA CENTRALNĄ EUROPE}

Społeczności w Italii i na ziemiach na północ od Alp zostały zaangażowane w interakcje handlowe już przynajmniej od czasów neolitycznych i przez pierwszą część późnej epoki żelaza w 500-300 r. p.n.e. Zarówno handel, jak i rozległe ruchy osób przez Alpy są widoczne w archeologicznych świadectwach. Z początkiem IV wieku p.n.e. najeźdźcy $z$ obszaru na północ od Alp zaatakowali miasta we Włoszech, nawet zajęli Rzym w 387 r. p.n.e. W kolejnych dwóch wiekach Rzym budował swoją obronę i wyruszył na militarną ekspansję na cały Półwysep Apeniński. Rzym rozszerzył swoje panowanie przez południowo-zachodnie Alpy do południowej Galii, gdzie ustanowił kolonię Galię Narbońską około 120 r. p.n.e. Pomiędzy 113 a 101 r. p.n.e. grupa nazywana Cymbrami prawdopodobnie z północnej Europy przesunęła się na centralne i południowe części Europy. Razem z innymi grupami, które się do nich dołączyły, Cymbrowie pokonali rzymską armię w serii bitew aż do momentu, kiedy w końcu zostali pobici pod Ferrarą w północnych Włoszech w 101 r. p.n.e. Wczesny IV wiek p.n.e. - atak na Rzym i w większym nawet stopnia wkroczenie Cymbrów i ich sojuszników w późnym II wieku p.n.e. miały głęboki wpływ na myślenie Rzymian na temat bezpieczeństwa północnej Italii i samego Rzymu, a także na temat charakteru mało znanych ludów spoza Alp. Towary, którymi handlowali Rzymianie, są dobrze reprezentowane w całej centralnej i zachodniej Europie od początku II wieku p.n.e., lecz rzymskie decyzje, aby wyruszyć na 
podbój Galii w 58 r. p.n.e. dowodzą wielkiego odejścia od wcześniejszych wzorów interakcji.

Trwa nadal debata na temat powodów decyzji Cezara, aby najechać Galię. Ostatnio w myśleniu przeważa podkreślanie polityki potęgi Rzymu w tym czasie i żądania Cezara dotyczących korzyści nad jego politycznymi rywalami. Przyjmuje się, że troska o ustanowienie bezpiecznej granicy na północy przyświecała zarówno decyzjom Cezara w Galii, jak i dalszym działaniom różnych cesarzy rzymskich w Europie Środkowej. Chcieli oni zapewne uchronić Rzym przed możliwymi przyszłymi zagrożeniami, np. atakiem takich grup jak Cymbrowie. Pomiędzy rokiem 58 a 51 p.n.e. Juliusz Cezar poprowadził rzymskie armie na podbój Galii - ziemie współczesnej Francji, Belgii i Niemiec na zachód od Renu. W roku 15 p.n.e. rzymscy generałowie Druzus i Tyberiusz doprowadzili do podboju ziem, które obejmowały Niemcy i Austrię na południe od Dunaju

Wypady przez dolny Ren na region pomiędzy Renem i Łabą miały na celu rozszerzenie rzymskiej imperialnej kontroli ziem aż do Łaby. Jednak porzucono tę ideę, kiedy trzy legiony pod wodzą generała Warusa zostały unicestwione w Lesie Teutoburskim w 9 r. n.e. W końcu w 83 r. n.e. rzymskie armie dokończyły podbój południowo-zachodnich Niemiec, ustanawiając nową imperialną granicę za pomocą linii i wału zwanego limes.

Krótko po podboju wyżej wspomnianych regionów administracja rzymska zorganizowała podział tego terenu na prowincje imperium. Obozy militarne zostały wzniesione wzdłuż linii granicznych, stolice prowincji i inne miasta ustanowione, a system dróg i mostów zbudowany. Szerokie zarysy tych procesów oraz poszczególne daty podbojów i w niektórych przypadkach ustanowienie baz wojskowych i miast znamy $z$ dokumentów pisanych. Lecz istotne zagadnienia dotyczące np. rzymskiej armii obejmującej dziesiątki tysięcy żołnierzy, jak również administracji i innych przedstawicieli imperialnych w prowincjach, które były zaopatrywane w dobra, tylko czasami znajduje swój wyraz w źródłach pisanych.

Ustanowienie granic na krawędziach krajobrazu podbitego przez Rzym i charakter wzorów politycznych, militarnych, społecznych, gospodarczych i religijnych, które rozwinęły się na przygranicznych terytoriach, stały się przedmiotem aktywnych badań w ostatnich latach. Ważne studia stref granicznych i zmian, które w nich zaszły, obejmują prace takich autorów, jak Dyson (1985), Barrett, Fitzpatrick i Macinnes (1989) czy Maxfield i Dobson (1991) oraz Whittaker (1994). Prace te zawierają szczegółową bibliografię.

Esej ten zamierza być tylko skromnym wkładem do szerokiego i gwałtownie rozwijającego się zakresu badań na temat granicy rzymskiej. W pracach tych przytaczane jest znaczenie wszystkich czynników, takich jak polityczne, religijne, gospodarcze, które zdaniem autorów także odgrywały ważne role w interakcjach między rodzimymi ludami a Rzymianami zajmującymi prowincje. Dla analizy systemów-światów ważne są jednak tylko czynniki gospodarcze. 
Wśród archeologów i historyków zajmujących się okresem rzymskim trwa debata na temat tego, ile osób przeprowadziło się z Italii do umiarkowanej Europy w rezultacie jej podboju. W dominującej opinii - względnie niewielu. Podstawowymi reprezentantami Rzymu w nowych prowincjach byli żołnierze, inne kategorie osób z rzymskiej Italii to administracja i kupcy.

\section{DOSTAWY I PRODUKCJA}

W odpowiedzi na pytanie o dostawy do rzymskiej armii powinniśmy podzielić dostarczane produkty na dwie kategorie: żywność i towary wytwarzane. Skoncentrujemy się w tym miejscu na produktach wytwarzanych. Podczas gdy zaopatrywanie oddziałów w żywność było nadzorowane przez państwo, to jeśli chodzi o towary wytwarzane, wydaje się, że państwo nie odgrywało aktywnej roli w dostawach przynajmniej podczas I i II wieku n.e. Wytwarzane towary, które były potrzebne oddziałom wojska, obejmowały przedmioty wymagane w służbie wojskowej, takie jak broń, narzędzia, ubranie, elementy stroju, paski skórzane, rzemienie, buty i namioty oraz towary używane na co dzień, takie jak ceramika. Jeżeli chodzi o informacje dotyczące tego rodzaju dóbr, jesteśmy całkowicie zależni od świadectw archeologicznych, ponieważ dostępne teksty nie mówią wiele na ten temat.

\section{W OBRĘBIE IMPERIALNYCH GRANIC}

Ostatnie badania (wspomniane wyżej) sugerują, że jeżeli chodzi o całość dóbr wytwarzanych, państwo rzymskie nie utrzymywało scentralizowanych systemów produkcyjnych dla armii. Zamiast tego każdy wojskowy obóz musiał stworzyć własną organizację - wybudować swoje własne warsztaty rzemieślnicze lub organizować lokalnych rzemieślników, aby dostarczali im potrzebne towary. Większość tej produkcji była wykonywana przez robotników w vici, czyli w miastach, które były powszechnie związane z obozami rzymskimi i które dostarczały szeroki zakres dóbr i usług dla oddziałów. Produkcja ceramiki była czasami zorganizowana na dużą skalę, chociaż tam także było wiele małych warsztatów; często małe wytwórnie produkowały ten sam rodzaj ceramiki. Większość dobrej ceramiki, szczególnie terra sigillata, była importowana, najpierw z Italii, a potem z nowo ustanowionych centrów produkcyjnych w południowej Galii, takich jak Lyon czy też La Graufesenque oraz z centralnej Galii (Lezoux). Później, gdy popyt na dobrą ceramikę nadal rósł, zarówno w obrębie prowincji, jak i za jej granicami, w niepodbitych obszarach, zakłady produkcyjne były umiejscawiane dalej na północ i na wschód. Niektóre z nich zintensyfikowały produkcję, aby zaspokoić potrzeby zarówno rzymskich obozów wojskowych, jak i osadnictwo cywilne. W centrum wytwórczym w Rheinzaubern w południowo-zachodnich Niemczech na przykład szacuje się, że każdego 
roku w warsztatach zostało wyprodukowanych ponad milion naczyń. Zidentyfikowano pewną liczbę istotnych składów garncarskich, w których ceramika była składowana na handel. Jeden taki skład został znaleziony w Kempten w południowej Bawarii, który zawierał duże ilości terra sigillata wykonanej nad Renem. Skład ten został pogrzebany, kiedy ogień zniszczył budynek w 160 r. n.e. Skład był umieszczony w domu kupca położonym w centrum rzymskiego miasta dokładnie po drugiej stronie ulicy od rynku. Ta sytuacja sugeruje względnie wysoki status tego kupca. Badacze nie zgadzają się co do tego, czy taka ceramika cyrkulowała na wolnym rynku, czy też była pod jakąś formą kontroli państwa. Mniejsze zakłady garncarskie także istniały i pewna część ceramiki była produkowana w wojskowych obozach. Żołnierze na stanowiskach wojskowych, włączając w to zarówno oddziały legionów z Italii, jak i wojska pomocnicze z prowincji, także używali ceramiki wytwarzanej w lokalnych społecznościach - zarówno naczyń gładkich, jak i malowanych. Ceramika ta często przedstawia bezpośrednią kontynuację tradycji ceramicznych z późnej epoki żelaza. Często rodzima ceramika na stanowiskach rzymskich jest nieodróżnialna od ceramiki na lokalnych przedrzymskich osadach. Wydaje się dlatego, że obrońcy imperium byli zależni od rodzimej produkcji rzemieślniczej dotyczącej niektórych podstawowych towarów niezbędnych do ich codziennego życia.

Chociaż ograniczone prace metalurgiczne i kowalskie prowadzono w wojskowych obozach, świadectwa archeologiczne zdecydowanie sugerują, że podczas I i II wieku n.e. większość metali wykonywano poza obozami w otoczeniu cywilnym często w vici, czyli w miastach związanych z bazami wojskowymi. Świadectwa obejmują dużą liczbę narzędzi metalurgicznych, które powszechnie pochodzą z takich miast, lecz nie z samych obozów wojskowych. Niektórzy badacze twierdzą, że w większej części wojsko nie było zaangażowane w produkcję metalu w ogóle, lecz organizowało całkowitą dostawę metali wyprodukowanych przez rodzimych rzemieślników. W niektórych przypadkach świadectwa produkcji dóbr metalowych dla oddziałów rzymskich są pozyskiwane w miejscach, które w innym przypadku nie mają jawnych związków ze stanowiskami rzymskimi. Oldenstein (Wells, 1980, 1993, 1996) cytuje znalezisko ze Seinheim nad Menem: dom z pozostałościami skrzyni, w której znaleziono złom z rzymskiego wojskowego wyposażenia. Narzędzia żelazne znalezione obok sugerują, że budynek ten był warsztatem, który produkował metalowe wyroby dla rzymskich oddziałów stacjonujących na tym obszarze.

Oldenstein i Wells (Wells, 1980, 1993, 1996) dostarczyli danych liczbowych, które stawiają to pytanie o produkcję cywilną na potrzeby armii rzymskiej w perspektywie ilościowej. Wzdłuż granicy górno-niemiecko-retyjskiej Oldenstein szacuje, że około 20000 żołnierzy służyło w tym samym czasie w późnym II i wczesnym III wieku n.e. Wells uważa, że około 90000 żołnierzy stacjonowało nad środkowym i dolnym Renem. Typowa broń dla każdego żołnierza obejmowała hełm, pancerz na ciało, tarczę, włócznię miecz i sztylet. Hełmy i uzbrojenie były wykonywane z żelaza i skóry, tarcze z drewna i skóry z żelaznymi opaskami przez front i żelaznym 
jelcem. Włócznie, miecze i sztylety były żelazne. W dodatku do rzeczywistego uzbrojenia każdy żołnierz nosił przeciętnie 10 czy więcej brązowych przedmiotów, włączając w to szpilki, klamry, końcówki taśm i różne ozdoby. Wynika więc $\mathrm{z}$ tego, że żołnierz rzymski potrzebował olbrzymiej ilości przedmiotów, nie tylko uzbrojenia.

Jeżeli każda wojskowa baza rzymska musiała organizować dostawy wszystkich czy większości tych dóbr od rodzimych producentów - świadectwa sugerują, że dostawy były zapewniane w ten sposób - to wówczas okupacyjne rzymskie siły były bardzo mocno zależne od lokalnych grup. Bez ustawicznej współpracy lokalnych producentów rzymskie przedsięwzięcie upadłoby. W takich relacjach między wojskami i administracją rzymską a lokalnymi producentami negocjacje i kompromis prawdopodobnie odgrywały większą rolę niż ćwiczenie siły nad rodzimymi ludami. I lokalni rodzimi rzemieślnicy, i lokalni przywódcy stali się grupą, z którą należało się liczyć. Oddziały rzymskie musiały z kolei wprowadzać znaczący dobrobyt i bogactwo do społeczności, które zapewniały im potrzebne towary. Taka wzajemna organizacja z pewnością miała wkład we wzrost intensywności działalności gospodarczej w prowincjach Galii i Germanii podczas I i II wieku n.e.

\section{POZA GRANICAMI}

Interakcje między rzymskimi prowincjami i ziemiami poza granicami są dobrze udokumentowane. Najbardziej oczywistym wskaźnikiem chronologii, zasięgu i charakteru interakcji są wielkie ilości rzymskich dóbr znalezione na wszystkich obszarach od imperialnej granicy w kierunku północnym tak daleko jak Norwegia, Szwecja, Finlandia i na wschód tak daleko jak Rosja. Towary wyprodukowane przez Rzymian obejmowały brązowe naczynia, szkło, ceramikę, srebro i złoto, monety, statuetki i biżuterię. Obiekty te często występują w wyjątkowo bogatych pochówkach, chociaż także na stanowiskach osadniczych.

Pisarze antyczni, szczególnie Tacyt czy Kasjusz Dion, dostarczają kolejnej perspektywy na interakcje Rzymian z ludami na wschód i na północ od granicy. Pisemne sprawozdania dotyczą głównie interakcji z ludami na obszarach blisko granicy i wyżej wymienieni dwaj autorzy starożytni wspominają, że dobra handlowe przychodziły do ziem rzymskich, takie jak woły, konie, niewolnicy, broń, zboże, bursztyn oraz skóry wołowe jako trybut. Źródła pisane nie są bardzo dokładne i nie dostarczają wielu informacji na temat źródła położenia czy ilości, jakimi handlowano. Inne dobra, które przenikały granice w handlu transgranicznym, obejmują futra, tekstylia, miód i wosk. Wnioskujemy o tym handlu na podstawie wiadomości o podobnych interakcjach w porównywalnych sytuacjach w innych czasach i miejscach. Tysiące wyprodukowanych przez Rzymian przedmiotów, które były znalezione za granicami, wskazują, że interakcje musiały być istotne i że jest to powód, aby sądzić, że dostawcy dla rzymskich oddziałów także handlowali przez granice. Na przykład 
w Tolsum w Holandii odkryto tabliczkę noszącą łacińską inskrypcję, która dokumentowała transakcję z rzymskim kupcem, który nabył bydło od rodzimego sprzedawcy. Tacyt piszący około 100 r. n.e. wspomina skóry wołowe jako trybut płacone przez Fryzyjczyków Rzymianom.

Obecny stan badań nie ułatwia bezpośredniego powiązanie dóbr, które dostawcy rzymscy otrzymywali od produkujących społeczności przez granice, $\mathrm{z}$ archeologicznymi świadectwami takiego systemu dostaw. Ale jest dobry powód, aby wnosić, że gwałtowna ekspansja działalności produkcyjnej metalurgii żelaza i chowu bydła $\mathrm{w}$ regionach blisko granicy była bezpośrednio związana z tym zaprowiantowaniem. Oddziały rzymskie potrzebowały wielkich ilości żelaza na uzbrojenie, narzędzia, gwoździe i na inne cele. Świadectwa archeologiczne w regionach przy granicach pokazują gwałtowne rozprzestrzenienie się, ekspansję produkcji żelaza podczas I, II i III wieku n.e., w czasie gdy rzymska armia ustanawiała i wyposażała swoje stanowiska graniczne. Przykładem takiej ekspansji może być stanowisko wytopu żelaza w Gera-Tinz w Turyngii, Riestedt w Saksonii - Anhalt i Barkow w Meklenburgii-Western Pomeranii. W Gera-Tinz na przykład badacze odkryli 21 pieców do wytopu na obszarze mierzącym $10 \mathrm{~m} \times 25 \mathrm{~m}$, związanych z pozostałościami małej osady datowanej przez towarzyszącą jej ceramikę na I, II i III wiek n.e. Znacząco produkcja na tych stanowiskach i na innych ziemiach poza granicami była przeprowadzana w licznych na małą skalę podejmowanych działaniach.

Nie odkryto dużych, wyspecjalizowanych miejsc produkcji żelaza w społecznościach, które produkowały nadwyżki metalu. Jedynym miejscem, które mogłoby świadczyć o takiej produkcji, są Góry Świętokrzyskie w Polsce, a więc obszar zlokalizowany w pewnej odległości od granicy z Imperium Rzymskim.

Wiele stanowisk, szczególnie na piaszczystych glebach na równinie północnoeuropejskiej, na północ i wschód od Dolnego Renu, wykazuje wzrost produkcji bydła. Wśród najlepszych dowodów jest ta z Feddersen Weerde na wybrzeżu Morza Północnego w pobliżu Bremerhaven w Niemczech. Osada została założona około połowy ostatniego wieku p.n.e. i była zamieszkana przez cały okres rzymski. W osadzie archeolodzy stwierdzili jakąś formę wurty czy też sztucznych pagórków ponad otaczającym płasko nisko leżącym obszarem. Zachowanie drewna było w tym wilgotnym środowisku wyjątkowo dobre. Charakterystyczne struktury na osadzie uznano za tzw. Wohnstallhaus - długi prostokątny budynek podzielony na część mieszkalną na jednym końcu i stodołę z oddziałami dla żywego inwentarza na drugim. Na podstawie analizy wielkości fundamentów stodoły w rożnych fazach zamieszkiwania na stanowisku próbowano oszacować wzrost w całkowitej wydajności bydła. Na całej osadzie wzrasta liczba domniemanych stodół, z 98 stajni na początku zamieszkiwania aż do 443 stajni podczas II i III wieku n.e. Również wzrasta wielkość importu z ziem rzymskich, który obejmuje terra sigillata, paciorki szklane i naczynia, monety i kamienie milowe. Świadectwa archeologiczne sugerują więc intensyfikację produkcji bydła podczas I i II wieku na stanowisku i towarzyszący jej 
wzrost wielkości importów rzymskich. Na tym samym stanowisku około końca I i początku II wieku n.e. archeolodzy zidentyfikowali świadectwa wzrastającej społecznej dyferencjacji. Ich zdaniem jeden budynek wyróżniał się zasadniczo, gdy był większy i bardziej istotny niż inne domy na stanowisku. Zawierał także więcej importów rzymskich datowanych na II i III wiek n.e. W tym samym okresie wiązano $\mathrm{z}$ nim także występujące $\mathrm{w}$ tym miejscu świadectwa produkcji metalurgicznej. $\mathrm{Na}$ początku III wieku potraktowano ten budynek jako specjalną część osady i oddzielono od reszty stanowiska palisadą. Obok niego stwierdzono obszar ogrodzony płotem, który zawierał spiżarnię i miejsca, gdzie rozwijano produkcję metalurgiczną. Haarnagel sugeruje, że mieszkaniec tej szczególnej budowli kierował produkcją rzemieślniczą i handlem dla całej społeczności. W ciągu III wieku widoczny w Feddersen Weerde jest spadek aktywności ekonomicznej. Proces ten ma trwać podczas IV wieku i ma swój rezultat w porzuceniu tego stanowiska w V wieku.

\section{DYSKUSJA}

Utrzymanie rzymskiej imperialnej granicy w centralnej Europie zależało od dostaw produkowanych przez lokalne grupy pracujące $\mathrm{w}$ tradycjach wytwórczych, które rozwinęły się w prehistorycznej epoce żelaza. W rzeczywistości istotna część dóbr dostarczanych do oddziałów rzymskich była wersją prehistorycznych materiałów z epoki żelaza. Ceramika i zapinki są dwiema kategoriami dóbr, które ilustrują ten wzór. Ceramika dostarcza ważnego dowodu, ponieważ jest ona dobrze zachowana i obficie reprezentowana zarówno na stanowiskach lokalnych, jak i rzymskich. Jednobarwna, wykonywana ręcznie ceramika, rzeczywiście identyczna $\mathrm{z}$ tą na stanowiskach późnej epoki żelaza, takich jak Manching, Altenburg i Kelheim, została odkryta na licznych osadach z okresu rzymskiego na przykład na terenie obozu wojskowego w Dangstetten nad górnym Renem czy też w Rottweil w Wirtembergii, a także w Kempten w Bawarii. Dobra ceramika wykonana na kole, dekorowana poziomymi i pionowymi pasami malowanymi czerwoną farbą odpowiada typowej kategorii ceramiki z późnej epoki żelaza i również pojawia się na wielu stanowiskach rzymskich, włączając w to Kempten i Straubing. Wiele zapinek, czyli spinek bogato zdobionych do odzieży, znanych ze stanowisk wojskowych, ma formy identyczne z lokalnymi typami z późnej epoki żelaza bądź z tymi, które wywodzą się bezpośrednio od nich. Tak więc jest oczywiste, że istotna część przedmiotów używanych w życiu codziennym na stanowiskach wojskowych rzymskich była wytwarzana przez rodzime grupy na otaczającym obóz terytorium, na którym wykorzystywano w produkcji lokalne, tradycyjne technologie i style.

Jak twierdzi Roymans, na podstawie danych holenderskich, wojsko rzymskie z pewnością pobudzało ekonomię rodzimych społeczności - zarówno w obrębie, jak i poza imperialną granicą - przez budowę systemu nabywania $z$ nich dóbr, które 
armia potrzebowała. Kiedy potrzeby rzymskiej armii rosły, niektóre grupy lokalne zmieniały swoją technologię i styl produkcji, aby dopasować go do potrzeb rzymskich okupujących armii. Przedmioty produkowane dla armii rzymskiej pożądane były także przez inne lokalne społeczności, do których trafiały one także z miejsc ich produkcji.

Ten proces przekształcania rodzimych tradycji rzemieślniczych jest dobrze ilustrowany w sekwencji produkcji ceramiki w Schwabegg w Bawarii. Szczątki pieca obejmujące typową ceramikę z późnej epoki żelaza na tym stanowisku potwierdzają produkcję w Schwabegg przed okresem rzymskim. Wcześniej w I wieku n.e. ustanowiono wyspecjalizowaną społeczność produkującą ceramikę na stanowisku, a do końca tego wieku stanowisko to stało się wysoce wyspecjalizowanym centrum produkującym dużą ilość różnorodnej ceramiki i obsługującym szeroki rynek. Wśród ceramiki wytwarzanej na tym stanowisku była dobra ceramika malowana na biało oraz w czerwone pasy, typ, który reprezentuje cechy ceramiki z późnej epoki żelaza. W późniejszym okresie na tym stanowisku zidentyfikowano 55 pieców. Ciągłość $\mathrm{w}$ tradycji wytwarzania jest widoczna nie tylko $\mathrm{w}$ formie i dekoracji naczyń tu produkowanych, lecz w nawet $\mathrm{w}$ tożsamości personelu - wysoka proporcja osobistych imion reprezentowanych $\mathrm{w}$ pieczęciach na ceramice to lokalne imiona celtyckie. W końcu II wieku n.e. przemysł ceramiczny w Schwabegg zaczął specjalizować się w wytwarzaniu terra sigillata. Produkty były wysyłane statkami do społeczności we wszystkich kierunkach i naczynia stąd pochodzące są zidentyfikowane w fortach na limesie i tak daleko na wschód jak prowincja Pannonia. Przykład produkcji ceramiki w Schwabegg wskazuje, że można postrzegać wzór dostaw wzdłuż granicy jako system interakcji zachodzących między wojskami rzymskimi, które były zależne od lokalnych producentów, i lokalną wytwórczością dopasowującą swoje tradycyjne technologie i style, aby pasowały do skali i gustu ich nowych klientów. Niektórzy lokalni wodzowie zwiększali swoje bogactwo i status przez organizację tego handlu i są oni reprezentowani w niezwykle bogatych pochówkach podczas tego okresu pochówki odzwierciedlające praktyki prehistorycznych rodzimych ludów, lecz z rzymskimi, jak również lokalnymi dobrami odkrywanymi w ich obrębie. Przykładem jest grób 8 w Nijmegen w Holandii datowany na okres między 80 a 100 r. n.e. Grób zawierał pozostałości kremacji umieszczone wewnątrz urny szklanej i liczne inne dobra w tradycyjnym stylu epoki żelaza i wyraźnie nierzymskie w stylu. Dobra obejmowały uzbrojenie (trzy włócznie i tarczę), zestaw 23 naczyń terra sigillata z produkcji w centrum w La Graufesenque w południowej Galii, liczne ozdobne naczynia szklane, pięć brązowych naczyń i zestaw do pisania. Tożsamość z Rzymem jest podkreślona przez ceramikę, naczynia szklane i przybory do pisania, lecz skład zestawu grobowego pokazuje, że należy do tradycji lokalnej przedrzymskiej.

Przykłady cytowane wyżej są tylko małą częścią coraz częściej zbieranego materiału, który wskazuje, że wiele elementów kultury materialnej, znanej jako kultura prowincjonalnorzymska, było $\mathrm{w}$ rzeczywistości wytwarzanych przez rodzime ludy na 
podbitych terytoriach, często używających technik wytwórczych i wyrażających style, które rozwinęły się bezpośrednio z ich przedrzymskiej tradycji rzemieślniczej epoki żelaza. Takie świadectwa, które dopiero teraz zwracają na siebie uwagę badaczy, niosą ze sobą zasadnicze pytanie: Co słowo „rzymski” oznacza w tym kontekście. Oczywiste jest teraz, że większość architektury i codziennej kultury materialnej, która jest klasyfikowana jako rzymska w centralnej Europie, nie była wykonywana przez Rzymian czy nawet obywateli rzymskich mieszkających w prowincjach, lecz raczej przez rodzime ludy, które po podboju znalazły się pod wpływem rzymskich struktur politycznych i wśród przekonującego wpływu mody rzymskiej. Jak świadectwa archeologiczne udowadniają, po podboju i nawet przed nim do pewnego stopnia rzymska kultura materialna i styl stały się bardzo popularne wśród większości populacji prowincji. Wydaje się, że większość chciała stać się Rzymianami w taki sposób, w jaki mogła, przez przyswojenie sobie wszystkich możliwych aspektów rzymskiej kultury materialnej, włączając w to ceramikę, ozdoby osobiste, ubrania, narzędzia i architekturę. Jako przykład takiego postępowania Agache demonstruje przyjecie wzoru rodzimej rzymskiej willi jako stylu zamieszkiwania, zaś Jones twierdzi, że istotne cechy rzymskich miast i miasteczek w centralnej Europie były sponsorowane i wznoszone przez lokalne elity w kontekście rodzimych rytuałów konkurowania. Widzimy więc, że pojęcie „rzymski”, kiedy jest użyte w odniesieniu do centralnej Europy, określa styl zarówno architektury, jak i ceramiki, uzbrojenia, ozdób i tak dalej, który był chętnie przejmowany przez lokalne ludy jako środek demonstrowania ich uczuć tożsamości z nową kosmopolityczną cywilizacją, pod której władzą żyli. Ta modalność rzymskiego stylu wśród rodzimych ludów nie trwała długo. Już podczas I wieku n.e. w obrębie wieku po podboju nowe style kultury materialnej mieszają się często z silnymi elementami prehistorycznych tradycji epoki żelaza rozwiniętymi w rzymskich prowincjach. Wśród najlepszych przykładów jest kilka nowych kategorii ceramiki, która była produkowana podczas I i II wieku w Europie Środkowej. Jedną z nich jest naczynie retyjskie, typ silnie wypalanego, polerowanego naczynia z dekoracją reliefową, który stał się ogromnie popularny w I wieku n.e. i był produkowany przez liczne lokalne warsztaty w Bawarii. Naczynie noryckie to kolejny nowy produkt I i II wieku. Był on wytwarzany w warsztatach ceramicznych na małą skalę i charakteryzuje się silnym wypaleniem, wykonaniem na kole garncarskim, ma gruboziarnistą i nierówną powierzchnię. Dekoracja jest w formie nacięć grzebieniem, wyciętych linii falistych i profilowanych krawędzi. Maier twierdzi, że naczynia noryckie, które ucieleśniają elementy z późnej epoki żelaza i jej tradycji ceramicznej, reprezentują wyrażanie rodzimej tożsamości, wyrażanie siebie jakby w opozycji do wzrastającej homogeniczności rzymskiej kultury materialnej.

Poza granicami rzymskimi nie ma żadnych świadectw eksploatowania przez rzymskie imperium surowców ze stref dalekich od rodzimych społeczności. Świadectwa sugerują raczej to, co Thomas D. Hall (1986) nazywa inkorporacją. Według modelu T. D. Halla inkorporacja jest procesem, w którym społeczeństwa niemające 
jeszcze państwa wchodzą $w$ interakcję z państwem imperialnym i stają się z nim związane ekonomicznie. Jako rezultat oba społeczeństwa przechodzą pewne zmiany w sferach gospodarczej i zarazem społecznej. Społeczeństwa niemające państwa odgrywają aktywną rolę w takich zmianach. Świadectwa archeologiczne ukazują wzrost w lokalnej wytwórczości metalurgicznej i produkcji inwentarza żywego, aby wytwarzać dostawy dla rzymskich prowincji, jak zanotowano w przykładach powyżej. Te zmiany, które są widoczne w wielu różnych regionach za granicą imperialną, obejmują tworzenie większych społeczności, rozwój nowych technologii, adaptację nowych stylów z prowincji rzymskiego świata i większe wyrażenie zróżnicowania społecznego w dużej mierze przez przyswajanie rzymskich luksusowych importów, lecz także przez ekstrawaganckie zaangażowanie rodzimej architektury i produkcji rzemieślniczej. Nie ma jednak świadectw ani archeologicznych, ani pisanych, które sugerowałyby, że Imperium Rzymskie sprawowało jakąkolwiek formę kontroli nad ludami poza granicą czy też nad ich produkcją dóbr, które były pożądane przez rzymskie prowincje. Świadectwa, które wymieniłam w tym artykule, typowe dla sytuacji w okresie rzymskim w centralnej Europie, sugerują, że należałoby kwestionować nawet zasięg, do którego imperium kontrolowało surowce i dostawy w obrębie swoich własnych granic. Jeżeli każda baza wojskowa była zależna od produkcji żywności, ceramiki i wyposażenia metalowego od rodzimych ludów, to model potęgi Rzymu i kontroli roztaczanej przez niego nie jest najlepszym sposobem badania tych relacji. Zamiast tego powinniśmy skierować swoją uwagę w stronę problemu negocjacji, interakcji i wzajemnego zainteresowania po to, aby zbliżyć się do zrozumienia relacji między władzą imperialną a rodzimymi grupami.

Rozważania te prowadzą do pytania, gdzie dokładnie i kto stanowił imperium, kiedy mówimy o prowincjonalnorzymskich działaniach na północ od Alp. Czyje interesy są reprezentowane przez pojęcie imperium i kto wydawał decyzje, aby rozszerzać te interesy? Świadectwa materialne sugerują, że chodzi w tym pojęciu o szeroki zakres różnych interesów i że traktowanie imperium jako zunifikowanej całości nie jest pomocne w zrozumieniu dynamiki obserwowanych relacji. Techniki archeologii pomagają nam zbadać te relacje szczegółowo i jako zmieniające się w czasie. Przykład Feddersen Wierde ilustruje, jak instruktywne takie przypadki mogą być, kiedy mamy świadectwa długotrwałej zmiany procesualnej we wzorach osadnictwa, strukturze lokalnej produkcji i handlu dalekosiężnego.

\section{BUDOWANIE MODELU: OD PRZYKLADÓW DO SCHEMATU ANALITYCZNEGO}

Imperium Rzymskie w centralnej Europie dostarcza instruktywnego przykładu do zadania pytań dotyczących imperialnych relacji z rodzimymi ludami zarówno w obrębie, jak i poza imperium z powodu nadzwyczajnie bogatej i dobrze przestu- 
diowanej bazy źródłowej. Możemy użyć tego kontekstu, aby rozwinąć schemat analityczny, który może być zastosowany z zyskiem w stosunku do innych sytuacji imperialnych relacji z rodzimymi ludami. $\mathrm{W}$ tym celu badaliśmy problem zaprowiantowania imperialnych sił wojskowych, ponieważ problem ten dostarcza wglądu w troskę o dostawy dla rzymskiej administracji. Podstawy bezpieczeństwa imperium w centralnej Europie to armia. Bezpieczeństwo Rzymu opierało się na oddzieleniu naddunajskich i nadreńskich prowincji od stref północnych zamieszkanych przez ludy uważane za barbarzyńskie.

Świadectwa odnoszące się do sposobów, dzięki którym armia rzymska rozwiązywała problem dostaw, zarysowane wyżej, powodują konieczność ponownego przemyślenia pojęć imperialnej władzy i imperialnej kontroli. Teoria systemów-światów, kiedy się ją stosuje do imperiów, widzi czasami działalność imperialną zbyt wąsko, nie bierze pod uwagę wielu lokalnych interakcji między przedstawicielami imperium a rodzimymi grupami. Te interakcje i ich różnorodność mogą być badane przez skoncentrowanie się na osadnictwie i cmentarzyskach o różnym położeniu zarówno w obrębie imperialnych terytoriów, jak i poza nimi. W rozważanych przypadkach konieczność zaprowiantowania oddziałów na granicy wskazuje potrzebę negocjacji i adaptacji po części armii i jej personelu. Te przykłady wskazują, że trzeba przeorientować poszukiwania sytuacji imperialnych, przenosząc uwagę badawczą od pytania o potęgę Rzymu i to, jak ona była używana, na pytania o interesy, wzajemną zależność i interakcje utrzymywane, aby rozszerzać interesy wszystkich stron zaangażowanych $\mathrm{w}$ proces dostarczania niezbędnych dóbr materialnych dla armii.

Wgląd oferowany w tym przypadku może być użyty, aby rozwinąć ogólny schemat analizy relacji między imperialną władzą a rodzimymi ludami, z którymi zachodzą interakcje. Oczywiste jest, że nie możemy zaakceptować bezkrytycznie treści źródeł pisanych, które przetrwały ze społeczeństw imperialnych. Przykład rzymski przedstawiony tu pokazuje relacje między imperium a rodzimymi grupami jako sytuacyjne. Rzymskie oddziały potrzebowały dostaw dóbr i one musiały zabezpieczyć te dobra przez organizację produkcji ustanowioną z lokalnymi grupami. Jakakolwiek bardziej szczegółowa analiza tych relacji musi skoncentrować się na ekonomicznej, społecznej i politycznej podstawie lokalnych ludów i objąć badanie takich zmiennych, jak środowisko, wielkość społeczności i organizacja oraz tradycje rzemieślnicze po to, aby zrekonstruować rozwój relacji handlowych między konsumentami rzymskimi a rodzimymi producentami.

Analizy muszą się zacząć od oceny potrzeb imperialnej władzy w poszczególnym środowisku, a potem zwrócić się w stronę ustanowienia potencjalnych źródeł dla spełnienia tych potrzeb. Stanowiska produkcyjne w ich kontekście występowania dostarczają danych dotyczących źródeł - w przypadkach charakteryzowanych powyżej piece do wypalania, piece metalurgiczne i stodoły do chowu bydła. Po tym jak źródła zostaną zidentyfikowane, analizy mogą zwrócić się w stronę dowodów 
dotyczących odpowiedzi lokalnych społeczności na możliwości prezentowane przez interakcje z przedstawicielami władzy imperialnej. Świadectwa będą w formie importowanych dóbr i lokalnej produkcji rzemieślniczej, która wykazuje wpływ interakcji na zmiany w lokalnych technologiach i stylach. Zmiany widoczne w rodzimych społecznościach, takie jak wzrost wielkości społeczności, ekspansja produkcji i narzędzi oraz wzrost zróżnicowania wyrażony w domach i grobach, mogą być włączone w tę analizę.

\section{SYMBOLE-ŚWIATY}

Zdaniem Grega Woolfa (1990, s. 54) najbardziej potrzebnym pojęciem w analizie systemów-światów świata rzymskiego wydaje się być kategoria dominacji symbolicznej. Jego zdaniem należy stworzyć trzecią kategorię, obok imperiów-światów i gospodarki-świata, w ramach której przewidziana będzie ponadregionalna dominacja osiągana przez formację społeczną, w której władza symboliczna i religijna podporządkowuje interesy polityczne i ekonomiczne innych grup społecznych.

Symbolizm jest zawsze postrzegany jako podpierający polityczne i ekonomiczne systemy-światy, lecz teoretycznie jest możliwe, że mógłby zaistnieć system-świat, w którym to porządek symboliczny podporządkowywałby sobie siły polityczne i ekonomiczne. Systemy symboli-światów musiałyby być ze sobą powiązane, ale nie powinny być one geograficznie scentralizowane. Nacisk na władzę symboliczną wydaje się potrzebny w analizie społeczeństw wczesnej epoki żelaza. Symboliczna władza niektórych dóbr luksusowych stających się prestiżowymi nie jest ujęta w żadnych tekstach starożytnych. Wydaje się, że dobra prestiżowe używane w kontekstach ceremonialnych raczej nie mogą być używane ze sobą zamiennie. Na pewno zademonstrowanie, że rozległe i potężne systemy-światy oparte na władzy symbolicznej istniały w pradziejach, byłoby znaczącym wkładem do naszego zrozumienia światowej historii.

\section{PODSUMOWANIE}

Prezentowane tezy Immanuela Wallersteina i ich aplikacja w okresie wpływów rzymskich są wysoce interesujące, chociaż również otwarte na krytykę z różnych stron. Na pewno należy zwrócić uwagę na brak precyzji kategorii Wallersteina charakteryzujących świat starożytny, takich jak mini-systemy, imperia-światy i gospodarki-światy przed kapitalizmem. Nieprecyzyjne jest również chronologiczne następstwo i wyłanianie się tych kategorii w historii świata.

Kolejna grupa krytyków podnosi nadmierny materializm, ekonomizm tej analizy. Być może nie jest prawdą, że to właśnie ekonomia determinowała wszystkie 
inne cechy społeczeństwa i historii. Wallerstein dał dowód w swoich pracach dotyczących późniejszego okresu, że kultura, etniczność, demografia i relacje gender są postrzegane jako wytwarzane przez warunki ekonomiczne.

Nie można jednak nie dostrzegać, że analizy Wallersteina stanowią pewną atrakcyjność dla archeologów, zwłaszcza archeologów społecznych. Dzięki temu, że pozwalają zajmować się szerokimi przestrzennie wzorami i oferują podstawę dla uogólnień na szerszą niż regionalna skalę.

\section{BIBLIOGRAFIA}

Alcock, C.

1993 Graecia Capta: The Landscapes of Roman Greece. Cambridge: Cambridge University Press.

Alcock, C., Altroy, T. N., Morrison, K. D., Sinopoli, C. M., (red.)

2001 Empires: Perspectives from archaeology and history. New York, NY: Cambridge University Press.

Barrett, J. C., Fitzpatrick, A. P., Macinnes, L. (red.)

1989 Barbarians and Romans in North - West Europe. Oxford: British Archaeological Reports International, 471 .

Braudel, F.

1976-1977 Morze Śródziemne i świat śródziemnomorski w epoce Filipa II (t. 1-2). Gdańsk: Wydawnictwo Morskie.

Ciesielska, A.

2012 Przemiany kulturowe na obszarze między Odra a Wista na przetomie starożytności i średniowiecza. Studium metodologiczne. Poznań: Wydawnictwo Naukowe UAM.

D'Altroy, T. N.

1992 Provincial Power In the Inka Empire. Washington DC: Smithsonian Institution.

Drinkwater, J. F.

1983 Roman Gaul. Ithaca: Cornell University Press.

Dyson, S. L.

1985 The Creation of the Roman Frontier. Princeton: Princeton University Press.

Ferguson, R. B., Whitehead N. L.

1992 The Vilent Edge of Empire. W: R. B. Ferguson, N. L. Whitehead (red.), War in the Tribal Zone: Expanding States and Indigenous Warfare (s. 1-30). Santa Fe: School of American Research.

Finley, M.

1985 The Ancient Economy. Berkley: University of California Press.

Frankenstein, S., Rowlands, M.

1978 The Internal structure and regional context of early iron age society in south-western Germany. Bullletin z Institute of Archeology, 15, 7368.

Freeman, $\mathrm{P}$.

1993 „Romanisation” and Roman Material Culture. Journal of Roman Archaeology, 6, 438-445.

Greene, K.

1986 The Archaeology of Roman Economy. Berkley University of California Press.

Haarnagel, W.

1979 Die Grabung Feddersen Wierde. Stuttgart: Franz Steiner Verlag. 
Hall, T. D.

1986 Incorporation in the World-System: Toward the Critique. American Sociological Review, $51,390-402$.

Hingley, R.

1982 Roman Britain: the structure of Roman imperialism and the consequences of imperialism in the development of a peripheral province. W: D. Miles (red.), The Romano-British Countryside. Oxford: BAR BS 103.

Jones, R. F. J.

1987 A False Start? The Roman Urbanisation of Western Europe. World Archaeology, 19, 47-57.

Kümmel, Ch.

2001 Frühe Weltsysteme. Zentrum und Peripherie-Modelle in der Archäologie. Tübingen: Marie Leidorf Verlag.

Oldenstein, J.

1976 Zur Ausrustung roemischer Auxiliareinheiten: Studien zu Beschlaegen und Zierat an der Ausrustung der roemischen Auxiliareinheiten des obergermanisch-raetischen Limesgebiet aus dem zweiten und dritten Jahrhundert n. Ch. Bericht der ROemsich-Germanische Komission, 57, 49-284.

1985 Manufacture and Supply oft he Roman Army with Bronze Fittings. W: M. C. Bishop (red.), The Production and Distribution of Roman Military Equipment (s. 82-94). Oxford: British Archaeological Reports International, Series 275.

Schörner, G.

2005 Das Zentrum-Peripherie-Modell in der ROmanisierungsforschung. W: G. Schörner (red.), ROmanisierung-ROmanisation. Theoretische Modelle und praktische Fallbeispiele. Oxford: BAR International, Series 1427.

Smith, M. E.

1986 The Role of Social Stratification in the Aztec Empire: a View from the Provinces. American Anthropologist, 88, 70-91.

2003 The Aztecs. Malden: Blackwell.

Wallerstein, I.

1975 The modern world system, t. 1: Capitalist agriculture and the origins of the European world-economy in the X $16^{\text {th }}$ century. New York, NY: Academic Press.

1979 The capitalist world economy. Essays by Immanuela Walelrstein. Cambridge: University Press.

1989 The modern world-system, t. 2: Mercantilism and the consolidations of European world economy. New York, NY: Academic Press.

Wells, P. S.

1980 Culture Contact and Culture Change: Early Iron Age entral Europe and the Mediterranean World. Cambridge: Cambridge University Press.

1993 Settlement, Economy and Cultural Change at the End of the European Iron Age: Excavations at Kelheim in Bavaria 1987-1991. Ann Arbor: Intenational Monographs in Prehistory.

1996 Production within and Beyond Imperial Boundaries, Goods, Exchange and Power In Roman Europe. Journal of World-Systems Research, 2(13), 1-14.

Whittaker, C. R.

$1994 \quad$ Frontiers of the Roman Empire. Baltimore: John Hopkins University Press.

Woolf, G.

1990 World-Systems Analysis and the Roman Empire. Journal of Roman Archaeology, 3, $44-58$. 


\title{
IMMANUEL WALLERSTEIN'S CENTRE-PERIPHERY THEORY AND ITS RECEPTION IN ARCHAEOLOGY, PART III IRON AGE
}

\author{
S u m m a r y
}

Immanuel Wallerstein's two important books have turned out to be a huge source of inspiration for archaeological studies. Strangely enough, they have been applied to pre-capitalist societies, which was not the main aim of their author.

In my article I analyze two main concepts which Wallerstein applies for pre-capitalist society: mini-systems, world-empire and world-economy. Scondly I attempt to answer whether the Roman Empire of the $2^{\text {nd }}$ century is the world-empire or the world-economy. The answer turns out to be difficult because it shows at the same time the main features of both empire and economy. But as a conclusion I propose using the concepts in new studies which may turn out to be very useful in building new schemes and frameworks of analysis.

Two German authors Christoph Kümmel and Günther Schörner has classified the studies of romanisation which apply Walelrstein's model. They have distinguished between the approaches that directly draw on the Walelrsteinian model, the case studies using only the concept of prestige goods system, the macrohistorical perspective and the studies dealing only with centre-periphery concepts without defining them.

In my article I chose to further discussion only the first category of studies. The works in this group are very fruitful and helped to establish potential new investigative questions. There are many works dealing with Wallerstein's scheme, but the most important of them are Richard Hingley study of Roman Britain, Peter S. Wells study of the Roman Empire and its influence into the temperate Europe and the concept of world-symbols created by Greg Woolf.

I have discussed these articles subsequently and at the end of my article I postulated some important key issues that should be studied and which emerges from the application of Walelrstein's model to archaeology of the Roman Empire. 